Let us entertain you. An exploratory study on the beliefs and practices of teaching history of education in the 21st century.

Nele Reyniers (corresponding author)

Centre for the history of education, KU Leuven, Leuven, Belgium.

Andreas Vesaliusstraat 2 - box 3761, 3000 Leuven, Belgium

nele.reyniers@kuleuven.be

Pieter Verstraete

Centre for the history of education, KU Leuven, Leuven, Belgium.

Andreas Vesaliusstraat 2 - box 3761, 3000 Leuven, Belgium

pieter.verstraete@kuleuven.be

+3216325882

Sarah Van Ruyskensvelde

Faculty of Psychology and Educational Sciences, Campus Kulak Kortrijk, KU Leuven, Leuven, Belgium.

Etienne Sabbelaan 53 - box 7654, 8500 Kortrijk, Belgium

sarah.vanruyskensvelde@kuleuven.be

+3216326287

\title{
Geert Kelchtermans
}

Centre for Innovation and the Development of Teacher and School, KU Leuven, Leuven, Belgium.

Dekenstraat 2 - box 3773, 3000 Leuven, Belgium

geert.kelchtermans@kuleuven.be

+3216326257 


\title{
Let us entertain you: An exploratory study on the beliefs and practices of teaching history of education in the 21st century.
}

\begin{abstract}
Following recent studies that have mapped history of education research practices, this article aims to map contemporary history of education teaching practices. Drawing on data from interviews with history of education university lecturers and a global digital survey, we explore the rationale behind teaching practices and teaching beliefs in history of education. The starting point for our interest was a shared 'sense of unease': we had the impression that those teaching practices and teaching beliefs were driven more by a concern to meet student's expectations and interests - to warrant their motivation and engagement - than by the content. The findings of our study provide evidence to support our concern. The contents, as well as the format of history of education courses is changing towards, what we provocatively would like to call, edutainment. This article aims to contribute to a critical self-reflection of history of education teaching worldwide.
\end{abstract}

Keywords:

history of education, teaching practices, teaching beliefs, edutainment, student consumerism

Number of words: 4550 words

In 2014, an ISCHE standing working group was established in order "to map the discipline history of education in Europe since the early nineties”. ${ }^{1}$ In the wake of this ISCHE project, two Paedagogica Historica articles also aimed at the mapping of the discipline. The first article was written by Edward Fuchs, one of the convenors of the above-mentioned ISCHE standing working group, and deals with 'the publication strategies and the associated

1 ISCHE stands for the International Standing Conference for the History of Education. On the following site you can find a description of this standing working group "Mapping the Discipline History of Education SWG (2014-2019)": http://www.ische.org/wpcontent/uploads/2016/03/SWG-_Map_HistoryEducation2015_2018.pdf (accessed May 4, 2018). 
institutional practices of ISCHE (...) and Paedagogica Historica'. ${ }^{2}$ The second article was published by Susanne Spieker and Angelo Van Gorp and focused on the history and impact of the EERA Histories of Education Summer School Conference for Postgraduates Students on networking and identification within the field of the history of education, between 2010 and $2015 .^{3}$

While the literature provides a clear overview of the state of the art in the history of education research, this is much less the case with regard to the way history of education is being taught. ${ }^{4}$ Since academic teaching is supposed to be research-based, an overview of the teaching practices and the teaching beliefs would be a necessary complement to the existing overviews of research. With our research project “Teaching history of education in/for the $21^{\text {st }}$ century" we aimed at contributing to that aim by mapping the existing beliefs and practices in history of education teaching around the globe. By 'teaching beliefs' we understand the underlying ideas, concepts and frameworks teachers use to perceive and make sense of professional situations and expectations and which act as the basis for their practices. 'Teaching practices', on the other hand, refer to the actual pedagogical enactment of those beliefs in the design, preparation and actual teaching activities. ${ }^{5}$

2 Eckhardt Fuchs, “The International Standing Conference for the History of Education and Paedagogica Historica: a historical view on institutional strategies and practices,” Paedagogica Historica, 50, no. 6, (2014): 737.

3 Susanne Spieker and Angelo Van Gorp, "Capacity building and communitas in the history of education,” Paedagogica Historica 52, no. 6 (2016): 768-83.

4 A notable and very recent exception is the edited volume of Elmar Lechner \& Marlene Petritsch, Statements zum Thema Didaktik der Historischen Pädagogik, (Klagenfurth, 2018).

5 See a.o. M. Frank Pajares, “Teachers' Beliefs and Educational Research: Cleaning Up a Messy Construct,” Review of Educational Research, 62, no. 3 (1992): 307-332; Geert Kelchtermans, "Who I am in how I teach is the message: Self-understanding, vulnerability, and reflection”. in: From teacher thinking to teachers and teaching: The evolution of a research community, ed. 
In order to collect our research data we first compiled a web survey. Given the fact that we were interested in the multiple, tangible and volatile teaching practices and beliefs of history of education in different parts of the world, we did not limit our study to one national context. Instead, the web survey was sent out globally. More in particular, we contacted members of editorial and scientific boards of history of education journals and keynote speakers at history of education conferences. We also got in touch with history of education lecturers, by consulting university webpages, and by asking national history of education societies to send around our call for participation in the project. We sent out the web survey 775 times and achieved a 30 per cent response rate (i.e. 229 participants filled in the survey). In total, 111 participants, coming from 24 different countries, filled out the questionnaire completely. This means that they filled in more than just the biographical information. ${ }^{6}$ In spite of the fact that we sent out the web survey globally, we mainly received American and European responses.

Since the aim of the web survey was to make an inventory of history of education teaching practices and beliefs, a broad range of questions covering several issues and subjects were included, such as the teachers' profile, the practicalities of the course, the course content, the teaching material, teaching methods, evaluation methods and the teachers' rationale.

Cheryl J. Craig, Paulien C. Meijer \& Jan Broeckmans, (Bingley (UK): Emerald Group Publishing, 2013), 379-401.

Ruth Kane, Susan Sandretto \& Chris Heath, "Telling half the story: a critical review of research on the teaching beliefs and practices of university academics,” Review of educational research, 72, no. 2 (2002): 177-228.

6 Lecturers that completely filled in the survey were based in the following countries: Argentina, Australia, Austria, Belgium, Brazil, Canada, Chili, , Greece, Finland, France, Germany, Hungary, Italy, Mexico, Portugal, Slovenia, South-Africa, Spain, Sweden, Switzerland, United Arab Emirates, United Kingdom, United States, Uruguay. 
In order to encourage respondents to participate in the survey, we deliberately restricted the number of questions, and used as much as possible multiple choice questions instead of open-ended questions. As a result, however, the web survey did not enable us to grasp the richness, the diversity and the changing nature of teaching practices and teaching beliefs of history of education courses worldwide. We therefore decided to include additional interviews with history of education lecturers. The selection of the interviewees was driven by a kind of "purposeful sampling”. Assuming that the existence of a national history of education society in a particular country, could be used as an indicator that history of education was effectively part of academic curricula in that country, we searched university websites of the countries with a history of education society to identify and get the contact details of lecturers of history of education.

Although we did aim at including data from every continent, we again were only able to get a response from European and (Latin-)American history of education lecturers. [Figure 1 near here]. ${ }^{7}$ Most of the 15 academic lecturers that responded to our query and were interviewed in the project were either historians with an interest in education, or educationalists with an interest in history. Also, most lecturers (i.e. 13/15) were affiliated to research units (departments or faculties) of education, or - to a lesser degree - to history or humanities sections in general. The majority of our respondents (i.e. 72\%) teach compulsory history of education courses at undergraduate or graduate level.

7 The history of education teachers, interviewed for this project, teach in the following countries:

Argentina, Austria, Belgium, Canada, France, Germany, Great-Britain, Italy, Latvia, Mexico, Netherlands, Spain, Sweden, United States.

All interviews were conducted by the first author. 


\section{History of education teaching practices and teaching beliefs}

In order to get an idea of how history of education courses are taught in higher education, we first explored the content of the courses. As far as the content of the courses is concerned, there is a rich variety among courses at different institutions and countries, which hampers comparisons. Nevertheless, it seems that the rationale of history of education courses are quite similar worldwide. Many respondents indicated that the purpose of their course was to raise students' awareness about the relevance of history for their future careers in education. First, for some interviewees, history is relevant because it "teaches you lessons and we have to learn history because we don't have to repeat the same mistakes”. ${ }^{8}$ Second, a majority (11 out of 15) indicated that history raises students' awareness about the complexity of the present and enables them to contextualize present-day problems. As a result, “understanding history helps us to understand why things are as they are and also that it could have been different”. ${ }^{9}$ History of education lecturers underline that our current teaching practices in education systems were only one of possible outcomes, and that various alternative systems could have existed. Last, studying history of education might stimulate critical thinking of educationalists by putting present-day issues in (a historical) perspective. Or as one lecturer put it: "You can’t be critical, if you don’t know history". ${ }^{10}$

The abovementioned quotes from the interviews reveal that the legitimacy for having history in a curriculum, lies in its 'being relevant for the present'. One interviewee stated: “Because history is, from my perspective, always about the present. Even though we're thinking historically, it always reflects on the present”. ${ }^{11}$ In spite of the fact that this line of thinking about history is not new, and can even be traced back to the very origins of the

\footnotetext{
8 Interview history of education teacher 2 (Mexico, February 22, 2017).

9 Interview history of education teacher 7 (Argentina, March 17, 2017).

10 Interview history of education teacher 9 (Spain, April 10, 2017).

11 Interview history of education teacher 11(Canada, April 18, 2017).
} 
discipline of the history of education, the interviewees' responses are an illustration of an increased concern with the relevance of history for the present. Whereas history of education was used to set a good example for students in teacher training, history of education is less focused on 'the great educators' or 'best education practices'. ${ }^{12}$ Instead, educational history fulfils the role of contextualising the present. History of education, so it seems, has transformed into a "historical perspective" ${ }^{13}$ that enables educationalists to compare educational practices in time and space and to identify long-term evolutions. Lecturers in history of education are convinced that students appreciate this different approach to teaching about the past: “'I'm really happy to find out about this history’, they [the students] say”14.

In that sense, 'relevant for the present' increasingly equals 'appealing to the students'. Generally, lecturers testified that they had achieved their goals when students were more aware of this particular approach to history, which is entirely different from history teaching in secondary education. In secondary schools, history is considered to be more “conventional” and "patriotic"15; an acts-and-facts history limited to the nation itself. Stepping away from this approach of history, is considered as a way to keep the course relevant and interesting for students ${ }^{16}$ and to keep them motivated.

In order to reveal how history of education lecturers want to achieve this, their different teaching practices and course materials were mapped. Although the way in which

13 Marc Depaepe, "De relevantie van het historisch-pedagogische onderzoek voor de pedagogische wetenschappen. Commentaar bij de discussie in het Nederlandse taalgebied,” Pedagogische Studiën,56 (1979): 505-521; Marc Depaepe, Qualities of Irrelevance? History of Education in the Training of Teachers, Knowledge, Politics and the History of Education, ed. Jesper Ekhardt Larsen, (Münster: LIT-Verlag, 2012), 39-53.

13 Interview history of education teacher 13 (Belgium, May 4, 2017).

14 Interview history of education teacher 6 (Mexico, March 13, 2017).

15 Interview history of education teacher 6 (Mexico, March 13, 2017).

16 Interview history of education teacher 13 (Belgium, May 4, 2017). 
history of education lecturers try to accomplish this goal differ, they all aim to motivate students, by making them understand the relevance of history. Students’ motivation is enhanced by using different techniques such as including their topical interests and using interactive teaching methods.

First, lecturers testified on the importance of responding to students' interests in particular topics within the history of education: "the design of the course is that we have a story to tell and then within the story students can choose what case studies appeal to them". ${ }^{17}$ This also results in lecturers dropping or changing particular topics that students are not interested in: "if you are seeing that at a moment they are not connected anymore you must change the topic". ${ }^{18}$

Hence, to some degree, the course design is tailored to students' interests, and history of education lecturers seem to be willing to drop or change subjects when students don’t like them or show little interest: "I myself enjoy that [the reading of a diary of a young boy in the Enlightenment] very much, but the students do not like it. So I reduce it to a couple of quotes, and that's it". ${ }^{19}$ Also, lecturers claimed that they included a more national or regional focus, and mainly deal with the $18^{\text {th }}, 19^{\text {th }}$ and $20^{\text {th }}$ century, in particular, because that is what students are interested in. The inclination towards the present or the very recent past in students' interests is nicely captured by the following quote: "if they [the students] think that you are talking about something that is more than ten years ago, they are not interested". ${ }^{20}$ Also: “Students are so, they are very focused on the very local concerns”. ${ }^{21}$ In other words, giving

17 Interview history of education teacher 12 (Great Britain, April 28, 2017).

18 Interview history of education teacher 10 (France, April 11, 2017).

19 Interview history of education teacher 5 (the Netherlands, March 10, 2017).

20 Interview history of education teacher 3 (Germany, February 24, 2017).

21 Interview history of education teacher 11(Canada, April 18, 2017). 
in to students' interest, actually makes teachers narrow down dramatically the time-space contours of what they would consider as possible curriculum content.

Secondly, lecturers try to use activating teaching methods and aim at explicit interaction with the students as a way to get or keep them motivated. As one of the lecturers pointed out, interactive and activating teaching methods are becoming more important: "we are (...) [increasingly] activating [our] teaching now”, what he/she demonstrated by giving the example of a teaching practice where "colleagues are also coming to the lecture and we are changing our views during this lecture”. ${ }^{22}$ Some universities even organise particular training courses for lecturers to stimulate them to use activating teaching techniques: "I have followed some specific courses, such as the use of a smartboard, the use of voting devices”. ${ }^{23}$ These activating teaching methods all aim to increase student motivation and engagement.

A third common teaching practice that was found in the gathered data features learning as an experience. One of the interviewees told that he/she goes to the library with the students for "the physical experience of go[ing] there and look at the catalogue, find them [books] and take them out of the shelves and smell them and feel them”. ${ }^{24}$ Another lecturer stressed the importance of showing real historical objects, because "it has a different impact when they can touch something or try it on or - or smell it. I think that is definitely meaningful”. ${ }^{25}$ What distinguishes these practices of the former examples, is the fact that in this case characteristics of history and historical research itself are being used to create a unique experience and catch students' interests. This way, both goals can be achieved: motivate students and make them aware of the relevance of history.

22 Interview history of education teacher 1 (Latvia, January 12, 2017).

23 Interview history of education teacher 13 (Belgium, May 4, 2017).

24 Interview history of education teacher 2 (Mexico, February 22, 2017).

25 Interview history of education teacher 3 (Germany, February 24, 2017). 
Finally, some respondents stressed the importance of one’s appearance and personal performance style as a lecturer in history of education in keeping students motivated: "Well I think one thing is just, is personality, is come with a - is being enthusiastic, is about your style of delivery, is convincing them, is telling jokes, doing accents. That are tricks to help them become engaged with it”, ${ }^{26}$

\section{Edutainment to save history of education teaching?}

As our findings, presented in the previous section, demonstrate, the lecturers of history of education courses feel that their teaching practices have become more student-centred, or more in particular driven by a concern to trigger students motivation by demonstrating the relevance of history for the present. The rationale for selection of the curriculum content, the beliefs about appropriate teaching strategies as well as an ongoing - implicit or explicit concern with the legitimacy for their discipline, seems to push lecturers in history of education to what we provocatively would like to call “edutainment”, a combination of “education” and “entertainment”. Legitimacy for teaching history of education as an academic curriculum content is no longer obtained by the content of the discipline, nor the expertise of the lecturers in that field, but the justification seems primarily to be found in the appreciation of its relevance for the present by the students. Furthermore, in terms of creating the necessary conditions of interest and motivation in the learners, lecturers feel they have to concentrate on pleasing and motivating them through appealing teaching methods as well as the promise of the content's relevance for the presence. So, both the justification (legitimacy) as well as the choice of content and teaching methods, is driven by students’ preferences.

This important transformation in the beliefs and practices of history of education lecturers begs the question: where did it come from, what made it emerge and develop? Based 
on the interviews we conducted, the results gathered from the web survey and a reading of the existing scholarship, we advocate that both the changing nature of doing history, as well as the changing university context, have influenced the content and teaching practices within the field of history of education.

First, we believe this transformation needs to be considered against the background of a more general tendency of edutainment within the field of history, which is illustrated by the increased importance of heritage, memory and public history, for instance. ${ }^{27}$ (Public) historians are increasingly concerned with making research results accessible for the wider public, and try to get 'their audience' interested in history. This has an effect on how we choose our topics, or how we (re-)present the past: we are increasingly wrapping it up in a nice package. There are numerous examples of this trend, ranging from television programs, over comic books to exhibitions and historical commemorations, that are commercialized into real spectacles and 'experiences'. The danger of such public events is that the historical narrative is reduced to a sensational story. What is the value of historical content, as different from the glitter and glamour of the show? The interviews and web survey suggest that, to some extent, history of education lecturers too are affected by this shift towards 'the sensational'. Yet, this development comes with a price.

The evolution demonstrates the increased influence of a consumer-approach to history and the representation of the past. Our findings on the teaching of history of education provide further evidence for this development and illustrate how students are treated and therefore socially constructed as ‘consumers' or 'clients'. Student-centeredness actually comes down to treating them as consumers, including the need to trigger their interest, meet

27 See for one example of how these new foci ended up in sometimes heated debates between proponents and adverseries: David Livingstone, The heritage crusade and the spoils of history. (Cambridge: Cambridge University Press, 2018). 
their expectations and provide arguments and justifications that make sense to them (rather than being driven by the content of the discipline). As such, the findings on teaching history of education fit in a development towards student consumerism, that is affecting teaching in higher education in a much broader sense, not limited to history of education. Long and Lake situate the origins of this process already in the sixties, when students increasingly demanded (and also got) permission to participate in decision-making in higher education institutes. Furthermore, budget cuts in universities, the decline in student enrolment in the 1980s and 1990s resulted in a "consumer mentality among students and their parents". ${ }^{28}$ In this sense, students are considered as consumers of knowledge. They are customers of higher education, and, as the saying goes, they are always right... [Figure 2 near here]. Yet the danger is that the curriculum in higher education, and course design, is first and even foremost - determined by student interests. What we teach, and how we teach, becomes less driven by the expertise and aims of the responsible teachers (academics with expertise in the content of the discipline), but results more and more from student interests. ${ }^{29}$

\section{A call for self-reflection}

The aim of this article has been to investigate teaching practices in the history of education worldwide. Already in 1999, Glenn Altschuler pointed to the “extent to which every class has become a show and every instructor a personality” in his paper 'Let me edutain you'. ${ }^{30}$ Around the same time, in 1993, Johanningmeier launched a plea for a more student-centred

28 Gary L. Long and Elise S. Lake, “A precondition for ethical teaching: clarity about role and inequality,” Teaching Sociology 24, no. 1 (1996): 111.

29 Emily Fairchild and Suzanna Crage, "Beyond the Debates: Measuring and Specifying Student Consumerism,” Sociological Spectrum 34 (2014): 403-20.

30 Glenn C. Altschuler, "Let me edutain you”, The New York Times, http://www.nytimes.com/1999/04/04/education/endpaper-let-me-edutain-you.html (accessed May 4, 2018). 
approach in the, at that time, existing history of education teaching practices. Many agreed on the matter, because who could be against the idea that "the interests and expectations of our students, if we are to be successful, must be considered as we define and organize our inquiries and organize our lectures”? ${ }^{31}$

More than two decades later and influenced by critical scholarship on university developments, Johanningmeier's and Altschuler's words almost sound prophetic to us. On the basis of a global web survey, and oral interviews with a selection of history of education lecturers from different countries, we found that history of education courses are influenced by the trends towards edutainment and student consumerism. It documents how, in history of education courses, the motivation and interests of students have become the central concern. History of educational lecturers try to make their courses attractive and fun. Also, the perceived need to demonstrate to students the relevance of the history of education for the presence, seems to have had an effect on the methods and content of history of education courses, that predominantly focus on the recent past and the local, regional or national context.

The interviews conducted in this project as well as the data gathered through the digital global survey suggest the need for a more detailed history of teaching practices and beliefs in the history of education. In recent years scholars rightly and increasingly have turned to the history of history of education research. The resulting narratives most of the time portray a successful discipline by generally focusing on e.g. the existence of history of education summer schools, the increase in the number of conferences and participants to these conferences and the growing amount of history of education journals. The findings presented in this article do not necessarily contradict the seemingly flourishing nature of the history of

31 Erwin V. Johanningmeier, "The history of education as a teaching subject: its nature, purposes, and methods," in Why should we teach history of education, ed. Kadriya Salimova and Erwin V. 
education discipline. They nevertheless contain an important warning and do urge history of education researchers/lecturers to critically reflect on the way history of education courses are given shape as well as on the underlying teaching beliefs.

Given the often intimated interconnectedness between history of education research and history of education teaching - in the sense that those who lecture in the history of education also are involved in academic research projects - it seems a quintessential question for historians of education to address in the near future how the move towards edutainment in history of education teaching practices and beliefs will affect the research agenda of historians of education and whether the tendency to please students/consumers will not eventually and ironically contribute to the loss of the discipline’s academic right of existence. 


\section{Biographical notes}

\section{Nele Reyniers (corresponding author)}

Nele Reyniers is affiliated as an educational assistant at the Centre for the History of Education of the University of Leuven, Belgium. She is currently working on a $\mathrm{PhD}$ proposal on the history of attention.

\section{Pieter Verstraete}

Pieter Verstraete is an assistant professor at the Centre for the History of Education of the University of Leuven, Belgium. His research interests comprise the history of educational initiatives for persons with disabilities, the role played by sounds/silences in our educational past and the importance attached to emotions in the history of education. Currently he is working on a book project that examines the cultural history of silence in the classroom.

\section{Sarah Van Ruyskensvelde}

Sarah Van Ruyskensvelde currently works as a post-doctoral fellow at the University of Leuven, Campus Kulak, where she teaches several history of education courses. Her research interests include the history of education during the two World Wars, the history of Catholic education, and the history of re-education initiatives in Europe.

\section{Geert Kelchtermans}

Geert Kelchtermans studied philosophy and educational sciences at the University of Leuven. He is a full professor at the same university, where he chairs the Center for Innovation and the Development of Teacher and School. His research focuses on educational innovation (with an emphasis on implementation practices), professional development (teachers, teacher educators and principals) and qualitative research methodology. The issue of the complex relationship between the individual educational professional (with his/her biography) on the one hand and the organizational and institutional context of the school (the work conditions) on the other runs as a red thread throughout his work. 


\section{Figures}

Figure 1: 'World map representing the different countries to which teachers of history of education that responded to the survey belonged' , 32

Figure 2: 'De Boeck, V., Cartoon Student Consumerism, 21-08-2017’

32 This map shows to which countries the survey respondents belonged. This cannot be interpreted as if there is no history of education in the other countries. What these grey areas on the map point out is the lack of respondents to our call, send out to the editorial boards of international history of education journals and (inter)national history of education societies.

This map was created by making use of the website: http://www.mapchart.net (accessed June 29, 2018). 